\title{
MEASURING CONTENT OF SOME CROATIAN BUSINESS NEWSPAPERS: ANALYSIS OF DOMESTIC AND FOREIGN BUSINESS COMPANIES - GEOGRAPHICAL ASPECT
}

DOI: http://dx.doi.org/10.18509/GBP.2018.41

UDC: 334.72:316.774(497.5)

\section{Jelena Lončar}

University of Zagreb, Faculty of Science, Department of Geography, 10000 Zagreb, Croatia

\begin{abstract}
Academic information suitable for academic research comes in many formats, but there are some common elements in deciding whether information is credible. As it is well known usual information sources are books(e-books); journal articles; newspaper articles; websites and other types and formatsprint and published electronically.In this research as the main source of information, newspapers aretaken. Measuring the content of newspapers can help bring informed decisions and, if repeated at appropriate intervals, it allows us to track content over time to measure figures and allows better choices.Information is very important in observing the competition by analysing new product developments, shifts in market share, individual company performance, and overall industry trends. Information helps managers anticipate economic and any other kind of changes, monitoring economic conditions at home and abroad and in short, they can provide answers to our questions.

In this research analysis of almost 500 numbers of different business newspapers printed/published online in Croatia is done with the main purpose to establish geographical context when measuring business news and taking into consideration number of domestic and foreign companies mentioned as well as economic sector of activity in which they operate. Analysis of headquarters of foreign companies and regions/cities in Croatia regarding domestic companies i.e. place where theyoperate has also been taken into consideration. In that way geographic focus, become clearer. Research was conducted in two periods: 2008-09 and 2014-15, i.e. period during and after economic recession. In that way author have tried to establish is the global recessioninfluenced (if any) on the changes that occur in the business content of analysed newspapers during researched period.
\end{abstract}

Key words:businessnewspapers, business information, business companies,Croatia

\section{INTRODUCTION}

We evaluate information hundreds of times each day. Whether we are considering buying a new car or choosing to believe an implausible story we have just heard, we are evaluating information and deciding whether it can be depended upon or disbelieved. Some information, such as a book published by a reputable publisher, has been reviewed by others first. Other information reaches us in unfiltered form [4]. Academic informationsuitable for academic research comes in many formats, but there are some common elements in deciding whether any information is credible. Common information sources arebooks, both in-print and published electronically (e-books); journal articles, 
both in-print and electronic; newspaper articles, both in-print and electronic; websites; other types, including social media, podcasts, newscasts, videos, etc. [4].

"Information can be used to evaluate the marketplace by surveying changing tastes and needs, monitoring buyers' intentions and attitudes, and assessing the characteristics of the market. Information is critical in monitoring the competition by watching new product developments, shifts in market share, individual company performance, and overall industry trends. Intelligence helps managers anticipate legal and political changes, and monitor economic conditions in the world. In short, intelligence can provide answers to two key business questions: How am I doing? and Where am I headed?" [6]

\section{METHODOLOGY}

The time needed to analyse newspaper content depends on the size of the newspaper. The more stories, listings and content promotions that are printed in a typical week, the more time it takes to complete analysis. Analysis time varies greatly depending on the level of detail desired. Basic analysis can be completed in approximately 10 hours; time needed, can expand to hundreds of hours for very detailed analysis [2].

One of the main methods for content analysis is comparison of different media in the context of introducing different social chain of events in them. Largest number of the research deals with written media, mostly newspaper texts. We also have to take into consideration that written media are much more developed, according to number and diversity, than electronic media in Croatia[3].

In this research analysis of almost 500 numbers of different business newspapers (Lider, Forbes - Croatian edition, Poslovni dnevnik and Banka) printed in Croatia is done with the main purpose to establish geographical context of measuring business news and taking into consideration number of domestic and foreign companies mentioned as well as economic sector of activity in which they operate. Analysis of headquarters of foreign companies andregions/cities in Croatia regarding domestic companies i.e. place where theyoperateis also takeninto consideration. In that way geographic focus, become clearer. These data are then compared with official statistics (form Croatian Bureau of Statistics) regarding trade balance between Croatia and other countries analysed in this research. Research was conducted in two periods: 2008-09 and 2014-15, i.e. period during and after economic recession. In that way author tried to establish whether the global recessionis well accompanied by business newspaper and are they objective and what (if any) changes occur in the business content of analysed newspapers during researched period.

\section{BUSINESS INFORMATION SOURCES}

Formal sources may be defined as those which are constituted in some regularized or legal manner in relation to the user, whereas informal sources have no such basis. Formal sources are often alsoimpersonal, and informal sources are likewise often personal; and so at first sight the pairs informal-personal and formal-impersonal seem to be synonymous, but this is not necessarily so [1].

As for business sources, information comes in general surveys, data, articles, books, references, search-engines, and internal records that a business can use to guide its planning, operations, and the evaluation of its activities. Such information also comes from friends, customers, associates, and vendors. Published sources may be daily newspapers; financial, trade, and association magazines; databases, government statistics, 
directories, technical manuals, and much else. In effect, since "information" is defined more by context than by content, business information is whatever information helps a business know its environment [6].

Business analysts cite two primary sources of business information: external information, in which documentation is made available to the public from a third party; and internal information, which consists of data created for the sole use of the company that produces it, such as personnel files, trade secrets, and minutes of board meetings [6].

Many of these databases offer information pertinent to the activities of business owners. Internet includes data on demographics and markets, economics and business, finance and banking, international trade, foreign statistics, economic trends, investment information, and government regulations and laws. This information is provided by Internet news groups, online versions of newspapers and magazines, and trade associations. Robert Fabian in CMA - The Management Accounting Magazine,claims, "Manycolleges, universities, libraries, research groups, and public bodies make information freely available to anyone with an Internet connection"."Often, the motivation is to make information available to people within the institution. But it can be less costly to provide general access than to screen access" [6].

Table 1. Information sources: Primary, Secondary, and Tertiary Sources, and Gray literature

\begin{tabular}{|c|c|c|c|c|}
\hline & Primary Sources & Secondary Sources & $\begin{array}{l}\text { Tertiary } \\
\text { Sources } \\
\end{array}$ & Gray Literature \\
\hline $\begin{array}{l}\text { Type of } \\
\text { work }\end{array}$ & $\begin{array}{l}\text { - Case studies } \\
\text { - Correspondence } \\
\text { - Diaries/ Personal } \\
\text { papers } \\
\text { - Dissertations/Theses } \\
\text { (Be sure to distinguish } \\
\text { betweenoriginal and review } \\
\text { material in thetext) } \\
\text { - Films: Original dramatic } \\
\text { / } \\
\text { artistic productions } \\
\text { - First-person accounts } \\
\text { - Historical } \\
\text { documents(Constitution, } \\
\text { treaties... \& copies) } \\
\text { - Laboratory data } \\
\text { - Minutes of meetings } \\
\text { - Original manuscripts } \\
\text { /documents } \\
\text { - Original research } \\
\text { - Photographs } \\
\text { - Religious } \\
\text { documents(Bible, } \\
\text { scripture...) } \\
\text { - Speeches } \\
\text { - Technical reports } \\
\text { - Works of fiction, } \\
\text { poetry,drama... }\end{array}$ & $\begin{array}{l}\quad \text { • Analysis } \\
\text { - Biography } \\
\text { - Criticism } \\
\text { - Dissertations/Thes } \\
\text { es (Literaturereview } \\
\text { materials) } \\
\text { - Editorials } \\
\text { - Film } \\
\text { documentaries } \\
\text { - Reviews of the } \\
\text { literature } \\
\text { - Work that relies } \\
\text { onprimary sources }\end{array}$ & $\begin{array}{l}\text { - Film } \\
\text { documentaries } \\
\text { - Work that is } \\
\text { basedentirely } \\
\text { on } \\
\text { secondarysourc } \\
\text { es }\end{array}$ & $\begin{array}{l}\text { - Conference } \\
\text { proceedings } \\
\text { - Data exchange } \\
\text { - Dissertations / } \\
\text { Theses } \\
\text { - Environmental } \\
\text { impactstatements } \\
\text { - Government } \\
\text { documents / } \\
\text { publications } \\
\text { - Market research } \\
\text { reports } \\
\text { - Online documents } \\
\text { - Oral presentations } \\
\text { - Technical reports } \\
\text { - Working papers }\end{array}$ \\
\hline Author & $\begin{array}{l}\text { - Authors reporting } \\
\text { onpersonalExperiences/ } \\
\text { work. } \\
\text { - In academics or } \\
\text { research,often written by }\end{array}$ & $\begin{array}{l}\text { - Author has an } \\
\text { interest in theTopic. } \\
\text { - Can be an expert } \\
\text { in the field. }\end{array}$ & $\begin{array}{l}\text { - Author has an } \\
\text { interestin the } \\
\text { topic. } \\
\text { - Free-lance } \\
\text { writers }\end{array}$ & $\begin{array}{l}\text { - Author works in the } \\
\text { field } \\
\text { - Expert in the field. } \\
\text { - Masters or PhD } \\
\text { candidates }\end{array}$ \\
\hline
\end{tabular}




\begin{tabular}{|c|c|c|c|c|}
\hline & $\begin{array}{l}\text { an expertor graduate } \\
\text { student in thefield. }\end{array}$ & & - Staff writer & \\
\hline $\begin{array}{l}\text { Where } \\
\text { published }\end{array}$ & $\begin{array}{l}\text { - Books } \\
\text { - Gray literature } \\
\text { - Monograph } \\
\text { - Scholarly journal } \\
\text { - Refereed/peer } \\
\text { reviewedjournal }\end{array}$ & $\begin{array}{l}\text { - Books } \\
\text { - Encyclopaedias } \\
\text { - Gray literature } \\
\text { - Newspapers } \\
\text { - Pamphlets } \\
\text { - Scholarly journal } \\
\text { - Refereed/peer } \\
\text { reviewed journal }\end{array}$ & $\begin{array}{l}\text { - Books / } \\
\text { textbooks } \\
\text { - Gray } \\
\text { literature } \\
\text { - Magazines } \\
\text { - Newspapers } \\
\text { - Trade } \\
\text { journals }\end{array}$ & $\begin{array}{l}\text { - Business / } \\
\text { Industrypublications } \\
\text { - Government } \\
\text { publications } \\
\text { (Federal, state \& } \\
\text { local) } \\
\text { - Unpublished } \\
\text { dissertation /Theses }\end{array}$ \\
\hline $\begin{array}{l}\text { Where } \\
\text { Found }\end{array}$ & \multicolumn{3}{|c|}{$\begin{array}{l}\text { Tertiary Literature can be found in a } \\
\text { ectronic databases. }\end{array}$} & $\begin{array}{l}\text { Gray literature is also } \\
\text { found in avariety of } \\
\text { print sources } \\
\text { andelectronic } \\
\text { databases, } \\
\text { thoughsometimes can } \\
\text { be harder to locate. } \\
\text { Some examples are: } \\
\text { - Caloosahatchee } \\
\text { Documents } \\
\text { - Charlotte Harbor } \\
\text { Info. } \\
\text { - Dissertation } \\
\text { Abstracts } \\
\text { - GrayLIT Network } \\
\text { http://www.osti.gov/gray } \\
\text { lit/ } \\
\text { - Library of } \\
\text { Congressloc.gov } \\
\text { - National Sea Grant } \\
\text { Lib } \\
\text { http://nsgd.gso.uri.edu/ } \\
\text { - NCJRSncjrs.org/ } \\
\text { - NOAA noaa.gov } \\
\text { - NTISntis.gov } \\
\text { - PapersFirst database } \\
\text { - Proceedings } \\
\text { - Scientific \& } \\
\text { Technical } \\
\text { Information Network } \\
\text { http://stinet.dtic.mil/ } \\
\text { - US Census Bureau } \\
\text { census.gov } \\
\text { - USDAusda.gov } \\
\text { - USGSusgs.gov } \\
\text { - Uno }\end{array}$ \\
\hline
\end{tabular}

Primary source: Original manuscript, documents or records used in preparing a published or unpublished work.

Secondary source: A published or unpublished work that relies on primary source(s).

Tertiary source: A published or unpublished work that is based on secondary sources.

Gray literature: Source material(s) not available through the usual systems of publication (e.g. books or periodicals) and distribution.

* Certain disciplines may use different criteria for identifying Primary, Secondary, and Tertiary literature. Source: Florida Gulf Coast University Library Services (library.fgcu.edu/RSD)

When evaluating newspaper articles it is very important to establish: 
Authorship- most authors who are published by a newspaper are free-lance or staff writers who investigate at topic area.Editors review the articles and content may be verified by fact-checkers.

Motive/intention - we can do a background search on anauth or on the web to find out previous history and publishing/research activity.Though newspaper reporters are expected to present a balanced story, everyone has a perspective.

Objectivity-are topics treated with balance and objectivity? Does the author consider the perspectives of other within the text? Does(s) he use weighted language or neutral language? Does(s)he backup her statements with specific evidence? Editorials and opinion pieces are not news articles, but are also published in the newspaper.They will feature a strong point of view.

Verifiable facts and references- references are not often given in news articles, so it is needed to independently verify the facts that we learn with other sources.

Currency-News articles are published very quickly and provide a good source to research rapidly changing topicareas.

Expert review- news articles are usually reviewed by editors andsometimes by factcheckers. Areputation by a reporteror thorough research is a good indicator of quality work.

Stability- newspaper articles are a stable source in print and when published simultaneously in print and in electronic versions.

Before getting started, first it is necessary to be selective in what we want to study. Content analysis works best when we are focus on a few key elements. Also it is necessary to recognize that designing questions can become complex. The idea must also be capable of objective measurement. There are many interesting aspects of content that are very subjective [2].

In addition, question arises, what other themes are suitable for researching in newspapers except business and economics? Themes vary from politics/government/legal to education, elections, natural disasters, sport, entertainment, food, religion etc.

\section{ANALYSIS OF CROATIAN BUSINESS NEWSPAPERS}

Mlačić and Mišetić (2009) when quoted Barelson (1952) highlighted that method of content analysis can be applied at large group of materials and those three main levels of content analysis use could be identified: characteristics of communication contents cause of content and consequence of content. Since the public communication is central aspect of social interaction and that operation of content analysis is administered directly on the texts which are concerning human communication, that indicators can be used for quantitative and qualitative relationship assessment between economic, social, political and cultural changes [3].

In this paper, four types of business papers are analyzed, which make half of published business newspapers in Croatia. Main difference between them is in the period of publishing (daily, weekly, and monthly) and the goal was to establish if there are any difference according to the number and diversity in the content according to the publishing period i.e. is there more focus on certain topics than in other newspapers, which are published less regularly.

All together almost 500 hundred numbers of mentioned business newspapers has been analyzed which gave the solid overview of its content, from which some parts are taken for analysis. In this case, those were business companies, economic sectors of their 
activities and their headquarters (according to the city/region - in Croatia and country foreign companies). This was important to research for establishing geographic focus of analyzed content.

Table 2. Analysed business newspapers

\begin{tabular}{|l|c|c|c|}
\hline Newspapers & Published & Analysed period & Number of analysed papers \\
\hline Poslovni dnevnik & Daily & $\begin{array}{c}\text { November-March 2008/09, } \\
\text { November-March 2014/15 }\end{array}$ & 200 \\
\hline Lider & Weekly & $\begin{array}{c}\text { November-March 2008/09, } \\
\text { November-March 2014/15 }\end{array}$ & 40 \\
\hline $\begin{array}{l}\text { Banka.hr } \\
\text { (on line edition) }\end{array}$ & Eonthly & $\begin{array}{c}\text { December-April 2008/09, } \\
\text { November-March 2014/15 }\end{array}$ & 10 \\
\hline Total & except Sunday & $\begin{array}{c}\text { November-March 2008/09, } \\
\text { November-March 2014/15 }\end{array}$ & 240 \\
\hline
\end{tabular}

In the newspapers all the news about companies are analysed. Supplements were also taken into consideration. When we mention the supplement we think of every individual unit no matter which journalist form belongs to, what it size is or content which it raises and which is physically separated from next unit i.e. next supplement. In that way,as supplement form is equallytreated an interview, which cover few pages, as well as smaller news, that takes only few percentage of the page, but represents individual and sensible unit [3].

Analyzing the content of business newspapers it is established that Croatian companies in the period 2008-2009 which are most mentioned are those in oil sector (INA), construction sector (INGRA), pharmaceuticals (Pliva), banking and financing (ZABA, HPB) as well as ICT sector and food industry (Podravka). Other types of industries follow. In smaller extent, companies from retail and service sector are present too. Generally, when analyzing content of newspaper most represented sectors are those from food industry, retail and then companies which are doing business in different economic sectors. In addition, banking, financing, services and other activities are present in the content.

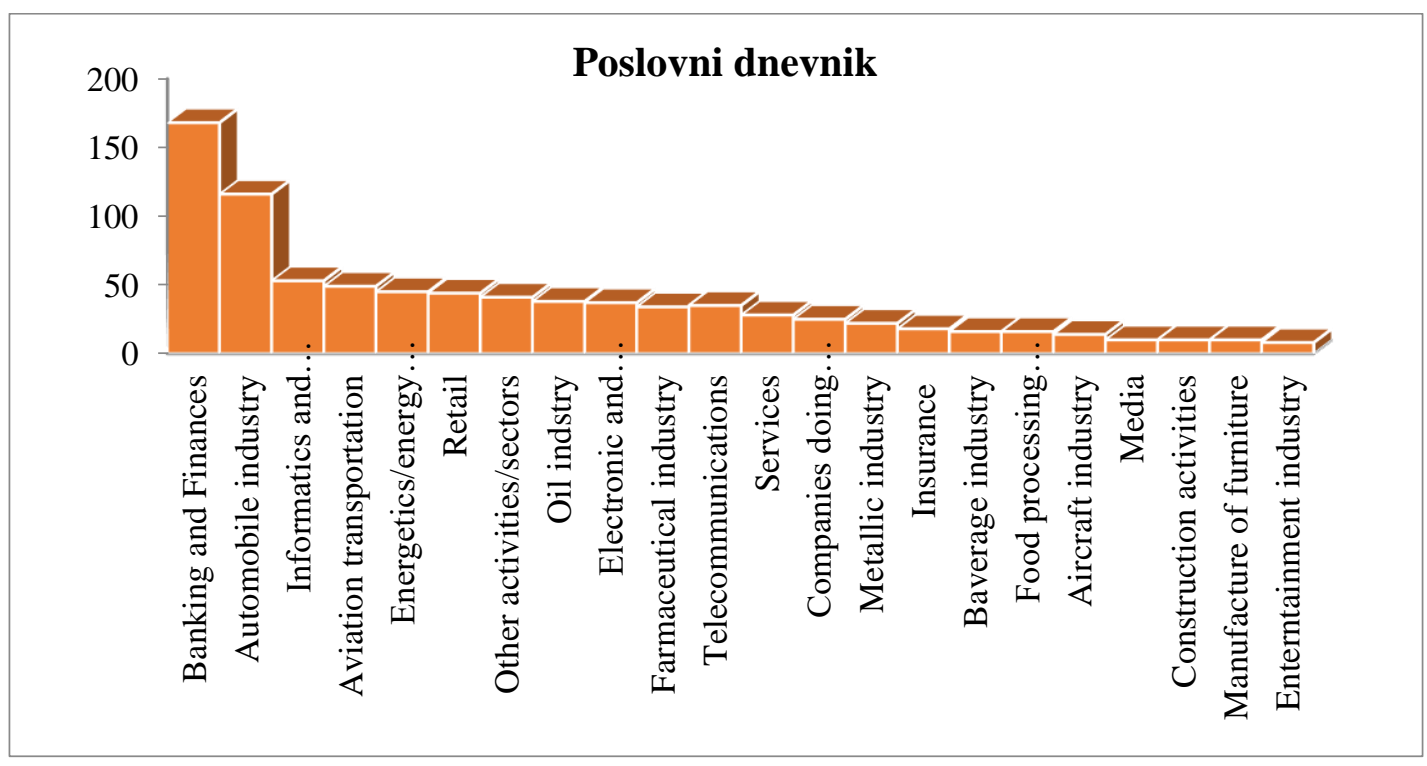




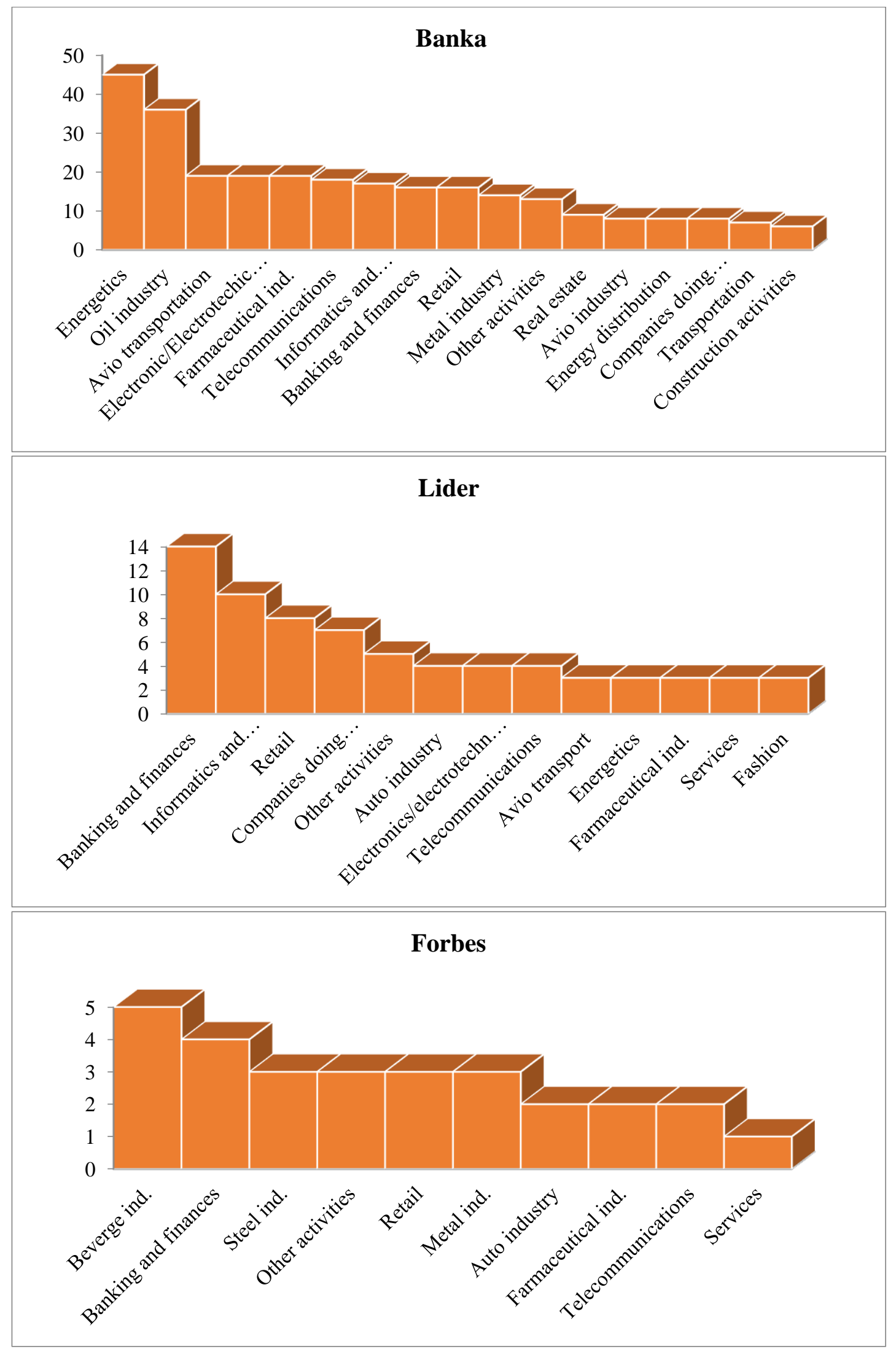

Figure 1. Frequency of appearance some economic sectors in analyzed business newspapers in the period 2008 to 2009. 
When analyzing foreign companies most common are those in banking and finance sector (Hypo Bank, Erste Bank, Reiffesen Bank, Uni Credit), oil sector (Gazprom, MOL), ICT (Yahoo, Apple) and automobile producers (General Motors, Fiat, Toyota, Ford). Companies in energy sector (CEZ, OMV) and other sectors follow them by. When analyzing frequency of mentioned economic sectors in the text, it is obvious directionality towards three sectors: oil industry, banking and financing and auto industry.

Investigating representation and frequency of content depending to regions and cities, mostly in Croatia, because foreign companies have been mentioned only according to the country of origin, we can make some geographic conclusions too.In accordance with the number of mentioned companies most common are those from Central Croatia (in 30-52 per cent of the cases), than from other Croatian regions - Eastern Croatia (11-25 per cent), Dalmatia or South Croatian littoral region (in 13-22 per cent of the cases) and then all other regions (North Croatian littoral region, Istria, Mountainous Croatia).

Out of cities, more than obvious is extent of content that concerns companies from City of Zagreb, which is logical because Zagreb is largest and most important economic center of the country. Zagreb is also in most cases, a place where domestic and foreign companies that are doing business in Croatia, have their headquarters. When measuring frequency of mentioning Zagreb in newspapers, this City is mentioned in 69-87 per cent of cases. The City of Zagreb is most frequently mentionedin the Forbs magazine. Other Croatian cities, mostly regional and county centers, like Rijeka, Osijek, Koprivnica, Rovinj and others, are mentioned less than 2 per cent.

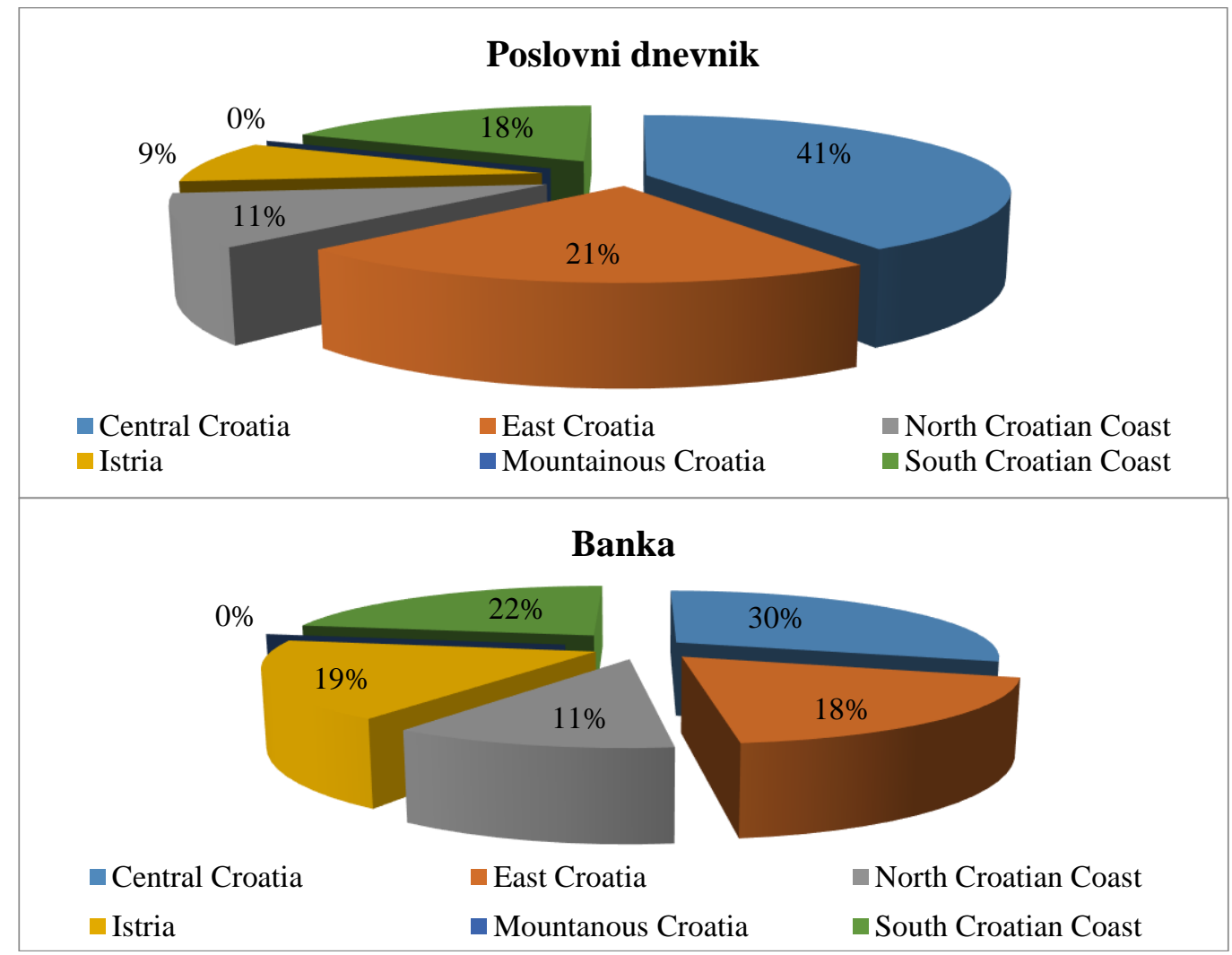




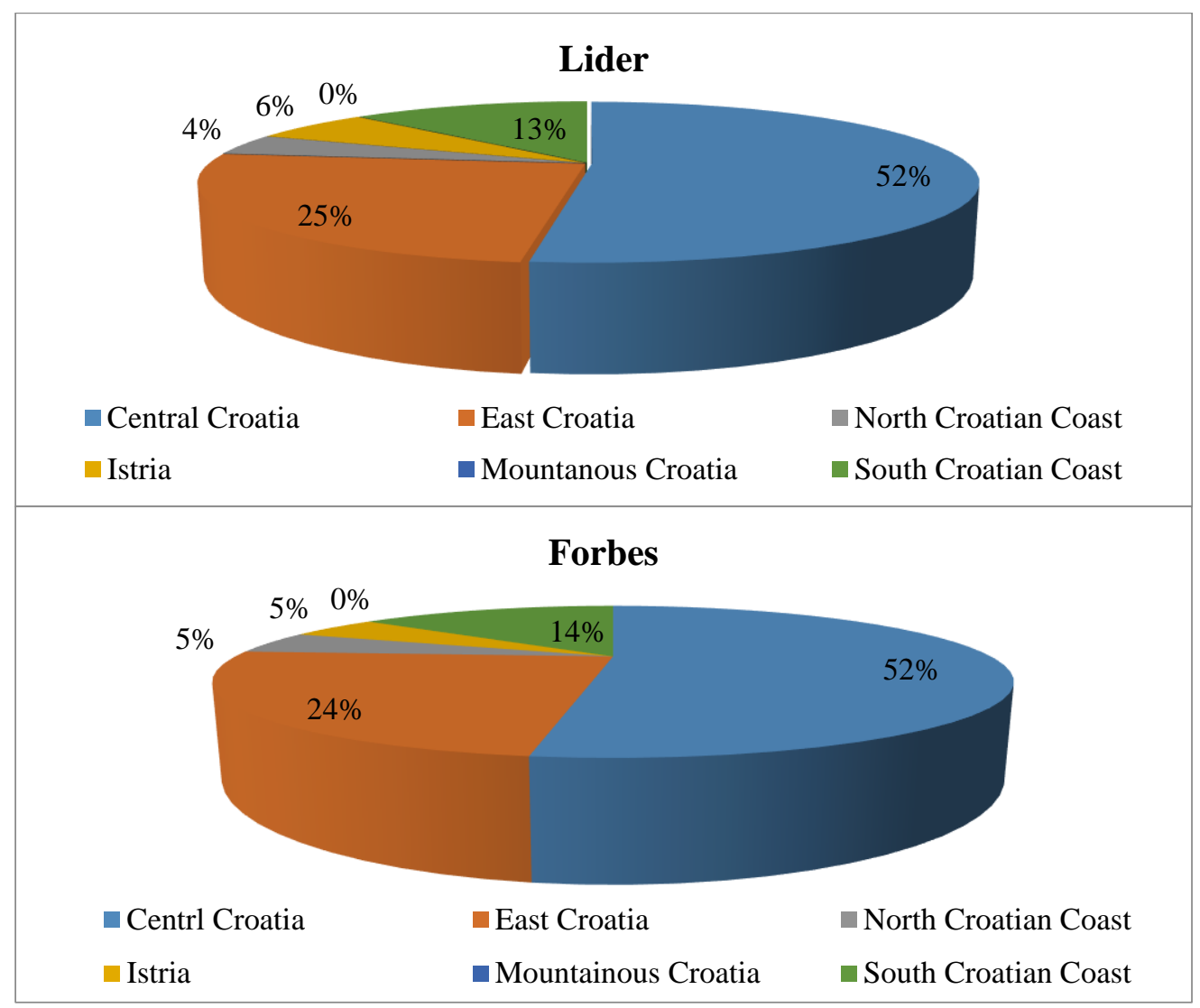

Figure 2. Frequency of appearance of Croatian regions in the content of analyzed newspapers in the period 2008-2009.

If we analyze foreign companies depending on their headquarters (in which country headquarter is) in the newspaper content, the most dominant country is U.S.A., followed by Germany, and some countries in Croatia vicinity like Slovenia, Italy and Austria. In less extent countries like France, Russia, Japan, United Kingdom (UK), Switzerland, China and others are mentioned.

When making content analysis of the same business newspapers for the period 2014-2015 in accordance with 2008-2009 some similarities, but also differences are discovered. For example, out of Croatian (domestic) companies most numerous, when analyzing content are those from food industry (Podravka), health sector (Imunološki zavod),oil industry (INA), and companies which are doing business in several different sectors (Adris grupa). They are followed by companies from machinery industry (Đuro Đaković, Končar), retail sector, shipbuilding and tourism.

When economic sectors were analyzed separately, most mentioned in the newspaper content were hotel industry and tourism, which is to be expected considering the role of these in Croatian economy.After tourism, most important sectors are food industry, banking and financing, ICTand then transportation. Therefore, in comparison to previous period (2008-2009), there is just slightly difference in newspaper content and their interest remained mostly the same.

Out of foreign companies most numerous are those from oil industry (MOL), retail companies (Mercator), ICT companies (Yahoo, Apple, Ericsson) and auto industries. However, there are some discrepancies in content when analyzing companies according to the period 2008-2009. 


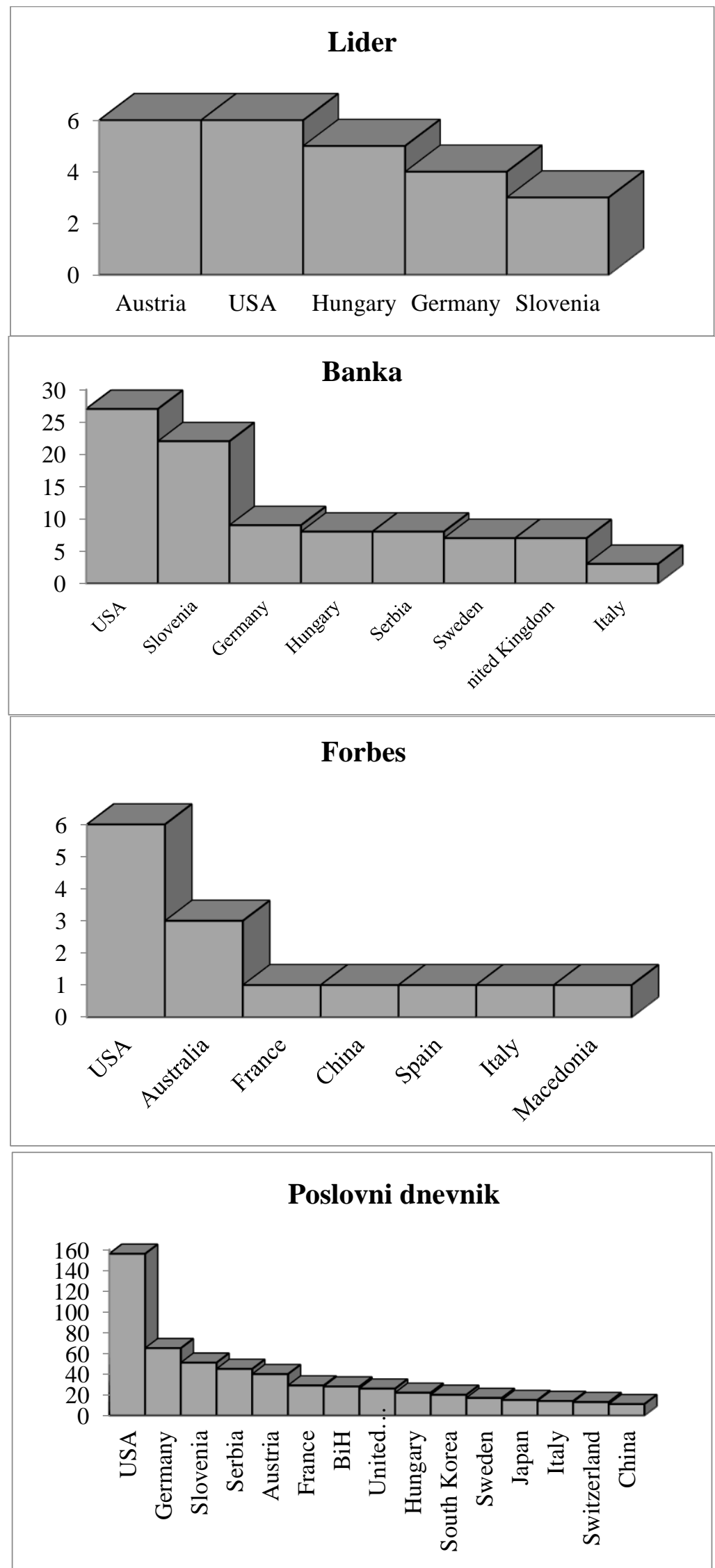

Figure 3. Frequency of companies according to the country of origin (headquarters) in 2014-2015 period 
In recent,period more attention is given to the companies from ICT sector, which is expected due to significance of development in new technologies, especially informatics and new software, which have great impact on contemporary business, but also everyday life. Greater extent of content is also dedicated to the social networks. Economic sectors, which are most included in the newspaper content in this period, are banking, energy, auto industry and ICT followed by air transport, retail and other sectors.

Following frequency of researched business newspapers when analyzing regions, it is still obvious dominance of companies from Central Croatia, although in somewhat smaller extent (33-44 per cent) than in the previous period. Other Croatian regions are more equally represented in this recent period, so their frequency is between 15-33 per cent. Nevertheless, some regions like Mountainous Croatia have smallest frequency in the content.

Out of cities, City of Zagreb is still the most significant, but little less than in previous period. The percent of mention is between 58-72 per cent, and as before largest number of mention is in Forbes magazine. Other cities, which are the part of newspaper content when analyzing companies are Rijeka, Split, Zadar, Koprivnica, Dubrovnik, Rovinjetc. Those are regional and smaller cities with emphasized business function.

When analyzing foreign headquarters, again most dominating are the companies from U.S.A., Germany, Slovenia, Serbia, Hungary and other from previous period analysis.

Analyzing complete geographical focus i.e.directionality of articles in newspapers on certain geographic area, it is obvious that in the period 2008-2009 news connected with international (global) companies (50,1 per cent) dominated, while domestic companies are mentioned in somewhat smaller extent ( 42,6 per cent). This is also a period in which world economic recession started so it is to be expected that the business activity of global companies had effect on smaller companies and smaller countries, which are dependent on them. Domestic companies are the least mentioned on local/regional level (7,3 per cent) which indicates their smaller significance in Croatian economy (and because of that, they are less interesting to business newspapers).

In the period 2014-2015 situation is changed and larger focus is registered on domestic companies (49,5 per cent) than on the foreign companies $(42,4$ per cent) in the content. We can say that domestic economy becomes more important for business newspapers, although local and regional companies are still neglected, and the least mentioned (tab.3.) in analysed content.

Table 3. Geographical focus of analysed business companies

\begin{tabular}{|c|c|c|c|c|c|}
\hline \multicolumn{3}{|c|}{$2008 / 09$} & \multicolumn{3}{|c|}{$2014 / 15$} \\
\hline & Frequency & Percent & & Frequency & Percent \\
\hline region & 152 & 7,3 & region & 145 & 8,1 \\
\hline national & 881 & 42,6 & national & 886 & 49,5 \\
\hline international & 1038 & 50,1 & international & 760 & 42,4 \\
\hline Total & 2071 & 100 & Total & 1791 & 100 \\
\hline
\end{tabular}

When analysing official statistics about export and import of Croatia, which gives us objective glance for comparison with analysed articles in newspapers, it is obvious that Croatia has most trade activity with countries of EU. Italy, Germany and Slovenia are the most important Croatian trading partners (for researched years) and this activity is adequately accompanied in analysed newspapers, i.e. the perception of importance of 
these countries for Croatia and its economy in business newspapers is good, which shows that they are more or less objective. Other neighbouring countries, besides Slovenia, are also very significant trading partner to Croatia, and their number of mentioning in analysed newspaper is also adequate.

However, the case is that in most first places in analysed newspaper content U.S.A. i.e. U.S. companies are mentioned, which is not objective as Croatia-U.S.A. trade balance is quite small when comparing to other countries i.e. trade partners. That also includes Croatian-US companies' cooperation. In this case, number of companies from U.S.A. mentioned in newspaper is not justified. The reason for that is mostly significance and global position of American companies in the world economy so writing about them in business newspaper is inevitable.

\section{CONCLUSION}

When making analysis of the same business newspaper content for the period 2014-2015 in accordance with 2008-2009 some similarities, but also differences are discovered. Most obvious similarity is in focus on certain economic sectors, although there are some new areas (for example social networks) which will become more and more interesting in following years. On the other hand some differences have been noticed in the text which are become more focused on domestic economy and companies during the analyzed years. Since Croatia become the member of EU in 2013, it was interesting to analyze how this process was covered in business newspaper. Global companies still have large space in the newspapers, but smaller than before. When comparing content all together it is also obvious that main trends in Croatia economy registered in the statistics) are not very important when choosing what topics and themes will be chosen as the part of business newspaper content. They are all choosing most attractive themes even if they are not so significant or donot have close connections with current economic situation which is concern of regular reader of the business newspaper/magazines.

\section{REFERENCES}

[1] Kaye, D. Sources of information, Formal and Informal, Management Decision, Vol. 33 Issue: 5,1995, pp.13-15, https://doi.org/10.1108/EUM0000000003898

[2] Lynch, S. \& L. Peer.Analysing Newspaper Content, A How-To Guide, Readership institute, Media Management Centre at Nortwestern University, U.S.A., 2002, pp. 1-76.

[3] Mlačić, B. \&Mišetić, R. Analiza sadržaja hrvatskog tiska o Hrvatskoj vojsci 1996-2006: deskriptivni i evaluativni aspekti, Institut društvenih znanosti Ivo Pilar, Hrvatska, 2009, 251-276.

[4] BettsS. Nelson: Evaluationg Information Sources, Reference Librarian, Post University, Waterbury, CT, http://post.edu/docs (29.9.2017.)

[5] Državni zavod za statistiku, Export and import, according to economic classification of countries, January 2015, www.dzs.hr(accessed 29.9.2017.)

[6] Business information sources, https://www.inc.com/encyclopedia/business-informationsources.html (accessed 29.9.2017.)

Poslovni dnevnik, numbers Nov 2008, 2014 - March 2014, 2015

Lider, numbers Nov 2008, 2014 - March 2014, 2015

Forbes - Croatia Edition, numbers Dec-April 2008-09, Nov -March 2014-2015

Banka, numbers Nov 2008, 2014 - March 2009, 2015

Florida Gulf Coast University Library Services, library.fgcu.edu/RSD (accessed 27.9.2017.) 